\title{
B Melanoma Antigen 1
}

National Cancer Institute

\section{Source}

National Cancer Institute. B Melanoma Antigen 1. NCI Thesaurus. Code C104494.

B melanoma antigen 1 ( $43 \mathrm{aa}, \sim 5 \mathrm{kDa}$ ) is encoded by the human BAGE gene. This protein may play a role in melanoma tumorigenesis. 